慶應義塾大学学術情報リポジトリ

Keio Associated Repository of Academic resouces

\begin{tabular}{|c|l|}
\hline Title & Changes in lens proteins induced at the early stage of cataractogenesis in cac (Nakano) mice \\
\hline Sub Title & \\
\hline Author & $\begin{array}{l}\text { 小林, 静子(Kobayashi, Shizuko) } \\
\text { 粕谷, 美南子(Kasuya, Minako) } \\
\text { 糸井, 素一(Itoi, Motokazu) }\end{array}$ \\
\hline Publisher & 共立薬科大学 \\
\hline Publication year & 1989 \\
\hline Jtitle & $\begin{array}{l}\text { 共立薬科大学研究年報 (The annual report of the Kyoritsu College of } \\
\text { Pharmacy). No.34 (1989.) ,p.77- 77 }\end{array}$ \\
\hline JaLC DOI & \\
\hline Abstract & \\
\hline Notes & 抄録 \\
\hline Genre & Technical Report \\
\hline URL & https://koara.lib.keio.ac.jp/xoonips/modules/xoonips/detail.php?koara_id=AN00062898-0000003 \\
\hline
\end{tabular}

慶應義塾大学学術情報リポジトリ(KOARA)に掲載されているコンテンツの著作権は、それぞれの著作者、学会または出版社/発行者に帰属し、その権利は著作権法によって 保護されています。引用にあたっては、著作権法を遵守してご利用ください。

The copyrights of content available on the KeiO Associated Repository of Academic resources (KOARA) belong to the respective authors, academic societies, or publishers/issuers, and these rights are protected by the Japanese Copyright Act. When quoting the content, please follow the Japanese copyright act. 


\title{
Changes in Lens Proteins Induced at the Early Stage of Cataratogenesis in cac (Nakano) Mice*
}

\author{
Shizuko KoBAYASHI, Minako KASUYA** and Motokazu ItoI*** \\ 小林静子, 粕谷美南子**, 系井素一***
}

As we were interested in the relationship between the changes of lens proteins and the $\mathrm{Na}^{+}$and $\mathrm{K}^{+}$levels, those chages in lens of cac (Nakano) mice at around the stage of appearance of the "pin-head" opacity were analyzed by two-dimensional electrophoresis (2D-PAGE).

The 2D-PAGE profile of lens proteins in 21-day-old cac mice differed from that in 27-day-old normal mice, even though the appearance of "pin-head" nuclear opacity (26-day-old) had not yet been observed in the lenses. Especially noticeable were great differences in the polypeptides associated with the $\alpha$-and $\beta$-crystallin subfractions, the appearances of which corresponded to an increase in a ratio of the amounts of $\mathrm{Na}^{+}$to that of $\mathrm{K}^{+}$in the lenses of defective mice. No dramatic decrease in the $\gamma$ crystallin fraction was observed until the mature cataract stage.

* 本報告は Exp. Eye Res. (1989) 49, 553-559 に発表.

** 白内障研究所

*** 京都府立医大眼科 